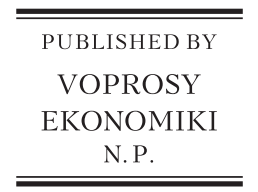

\title{
Investment drought in the Russian economy: Structural characteristics and turnaround perspectives
}

\author{
Olga Berezinskaya
}

Russian Presidential Academy of National Economy and Public Administration, Moscow, Russia

\begin{abstract}
The investment drought of 2013-2015 in Russia is the first prolonged period of no capital investment growth in the last 17 years. After stagnation in 2013-2014, fixed capital investments in real terms have systemically lagged behind industrial output growth and GDP. Lack of capital expenditures not only lowers demand and inhibits growth of construction, machinery, industrial production and the economy as a whole, but also preserves existing structural imbalances and technological gaps in the Russian economy. The duration of investment drought and its significant disincentivizing effect on current and expected growth of the Russian economy suggest the importance of analyzing structural characteristics of the investment process and triggers of capital investment.

(C) 2017 Non-profit partnership "Voprosy Ekonomiki”. Hosting by Elsevier B.V. All rights reserved.
\end{abstract}

JEL classification: E22.

Keywords: fixed capital investments, investment drought.

\section{Introduction}

In recent years, fixed capital investments in Russian companies have deteriorated dramatically. Following minor growth in 2013 and minor decline in 2014, investments plummeted by $8.4 \%$ in 2015. Over the past 17 years, 2013-2015 is the first lengthy period of stagnation in fixed capital investments (Fig. 1).

The recovery of investment activity in the Russian economy began in 1999, after a nearly fivefold real reduction of fixed capital investments from 1991 through

\footnotetext{
th The updated English version of the article published in Russian in Ekonomicheskaya Politika, 2016, No. 3, pp. 30-45.

E-mail address: Berezinskaya@ranepa.ru

Peer review under responsibility of Voprosy Ekonomiki.
} 


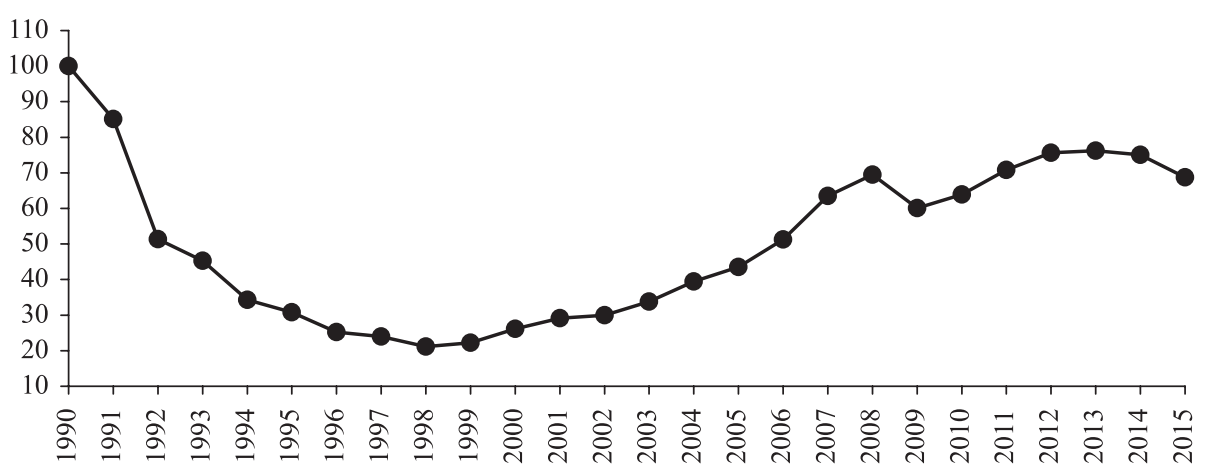

Fig. 1. Fixed capital investments in companies, 1990-2015 (in constant prices, 1990=100\%). Source: Rosstat.

1998. Significantly high annual average investment growth rates during a period of balanced economic growth (10.9\% per year, 1999-2005) accelerated during a period of growth due to strong demand (16.9\% per year, 2006-2008). During the acute stage of the crisis, fixed capital investments decreased by $13.5 \%$; this decline was overcome within two years. The average annual increase in fixed capital investments from 2010 to 2012 was slightly below $8 \%$, which was substantially lower than in 1999-2008.

Over the ten years between the 1998 and 2008 crises, the low base effect was substantially depleted, the stimulation of investment with high global prices for Russian export and capital inflow came to an end, while global economic downturn and resource restrictions became primary restraining factors.

Fixed capital investments peaked in 2012 and 2013 (in constant prices), exceeding the level in 1998 by nearly 230\%. During the following three years corresponding to the investment drought period, fixed capital investments declined by more than $9 \%$. As a result, by the end of 25 years of economic development, fixed capital investments are still noticeably lower than they were in the early 1990s; the fixed capital investment level in 2015 is hardly $69 \%$ of their level in 1990.

During the periods of recovery, growth driven by high demand, crisis, and the subsequent adjustment growth, fixed capital investments contributed to stronger demand, stimulating current business activity and improving the future technological capacity of Russian economy. In 1999-2012, the 14 years preceding the investment drought period, fixed capital investments outpaced GDP by nearly $260 \%$ in real terms, while the GDP doubled and the Russian industrial output increased by approximately $80 \%$.

In contrast, during the investment drought from 2013 to 2015, fixed capital investment dynamics was systematically worse than the trend for industrial output and GDP (Berezinskaya, 2016a). The reduction in GDP and industrial output began later than the reduction in fixed capital investments. It was also far less prominent: in real terms, over the three-year period, industrial output decreased by $1.4 \%$, GDP declined by $1.8 \%$, while fixed capital investments dropped by over $9 \%$. The investment drought suppressed the domestic demand in the economy, thus decelerating growth in construction, machinery and equipment, industry, and the economy as a whole and preserving the existing structural imbalances and 
technological decay of the Russian economy (Aganbegyan, 2015; Berezinskaya and Vedev, 2014).

The recent declining trend in fixed capital investments, the protracted nature of the investment drought, its significant negative effect on the current and future economic growth, the preservation of resource constraints, and significant growth in investment projects costs (Vedev and Kosarev, 2014) all call for a comprehensive analysis of the investment process in the Russian economy. This analysis will help identify relevant parameters and opportunities for overcoming the investment drought.

\section{Typical structure of fixed capital investments}

In terms of the structure of fixed capital investments by type, the investment drought period is characterized by the following:

- nearly stable investments (in nominal terms) in machinery, equipment, and transport (around RUB 5.05 trillion from 2012 to 2015);

- renewed increase in investments in non-residential buildings (from a relatively stable RUB 5.6 trillion from 2012 to 2014, to RUB 6.0 in 2015);

- gradual growth in residential real estate (from RUB 1.5 trillion in 2012, to RUB 2.2 trillion in 2015). Supported by state funding, this type of investment accounted for a significant portion of the total increase in fixed capital investments in nominal terms (Table 1).

This model for expanding fixed capital investments is not typical for the Russian economy (Table 2). Growth during periods of active investment was driven by

Table 1

Fixed capital investments by type, 2005-2015 (RUB trillion).

\begin{tabular}{llllll}
\hline & 2005 & 2008 & 2009 & 2012 & 2015 \\
\hline $\begin{array}{l}\text { Investments, total } \\
\text { including: }\end{array}$ & 3.6 & 8.8 & 8.0 & 12.6 & 14.6 \\
$\quad$ & & & & & \\
$\quad$ Residential real estate & 0.4 & 1.2 & 1.0 & 1.5 & 2.2 \\
$\quad$ Non-residential real estate & 1.5 & 3.7 & 3.5 & 5.6 & 6.0 \\
$\quad$ Machinery, equipment, and transport & 1.5 & 3.3 & 3.0 & 4.7 & 5.1 \\
$\quad$ Other & 0.2 & 0.5 & 0.5 & 0.8 & 1.3 \\
\hline
\end{tabular}

Source: Rosstat.

Table 2

Composition of fixed capital investment growth by type, 1999-2015 (\%).

\begin{tabular}{|c|c|c|c|c|c|}
\hline & 1999-2005 & $2006-2008$ & 2009 & 2010-2012 & 2013-2015 \\
\hline & $\begin{array}{l}\text { balanced } \\
\text { growth }\end{array}$ & $\begin{array}{l}\text { growth due } \\
\text { to strong } \\
\text { demand }\end{array}$ & $\begin{array}{l}\text { acute } \\
\text { stage of } \\
\text { the crisis }\end{array}$ & $\begin{array}{l}\text { adjustment } \\
\text { growth }\end{array}$ & $\begin{array}{l}\text { enhanced } \\
\text { growth } \\
\text { limitations }\end{array}$ \\
\hline $\begin{array}{l}\text { Investments, total } \\
\text { including: }\end{array}$ & 100 & 100 & 100 & 100 & 100 \\
\hline Residential real estate & 11 & 15 & 19 & 11 & 33 \\
\hline Non-residential real estate & 40 & 44 & 32 & 45 & 24 \\
\hline $\begin{array}{l}\text { Machinery, equipment, } \\
\text { and transport }\end{array}$ & 43 & 35 & 42 & 38 & 16 \\
\hline Other & 6 & 6 & 6 & 6 & 27 \\
\hline
\end{tabular}

Source: Rosstat. 
investments in non-residential real estate and investments in machinery, equipment, and transport, which accounted for approximately $40 \%$ of the nominal investment growth. From 2013 to 2015, the contribution of these key categories decreased to $16 \%-24 \%$.

Government support in the form of favorable mortgage terms helped overcome the trend of decelerating growth in housing investments, which led to both revitalization of this type of investment and nominal expansion of total fixed capital investment from 2013 through 2015. However, to restore a sustainable positive trend in the investment process, we need to return to robust investment in non-residential real estate, as well as in machinery, equipment, and transport.

The major share of investments in non-residential real estate is realized by large- and medium-sized construction and oil-and-gas companies, each of them contributing from one-sixth to one-third of this type of investment in 2005-2015. Until 2013, active capital expenditure policy in the construction industry translated from voluminous orders related to the 2014 Olympics, along with other large-scale projects. However, during the investment drought period, investments in non-residential property by large- and medium-sized companies decreased in nominal terms from RUB 1.64 trillion in 2012 to a mere RUB 1.22 trillion in 2015. These capital expenditures are thus primarily aimed at maintaining the existing production base as opposed to significantly expanding it. This is a result of a decline in demand in recent years for new complex construction projects. Reversing this negative trend may be possible by increasing capital expenditures in other industries and particularly investment in new construction projects.

Given these investment changes in the construction industry, it is important to maintain the trend of capital expenditures in non-residential property by large and medium-sized companies in the oil-and-gas sector. Following a rather slow growth rate until 2012, this type of investment increased from RUB 1.04 trillion to RUB 1.63 trillion in 2015. More difficult conditions for producing fossil fuels and potential new pipeline construction projects may support the current positive trend in non-residential real estate investment.

Finally, it is important to restore the growth of investment in non-residential property by companies in other industries. While before 2012 their investment in non-residential real estate was increasing annually on average by RUB 0.4 trillion, during the investment drought of 2013-2015, these investments grew only by RUB 0.1 trillion per year. This fourfold reduction was a result of the overall decline of investment in the economy.

Investments in machinery, equipment, and transport became weaker than those in real estate as early as in 2006-2012 - during the investment drought period, this problem only deepened.

From 2006 through 2012, insufficient competitiveness of Russian machinery, transport and equipment explained a limited change in domestic demand and a greater dependence on imported equipment and machinery. During the period of economic growth, driven by high demand, fixed capital investments increased by $59.7 \%$ in real terms. Even after adjustment for decelerated growth in machinery, equipment, and transport investments from 2006 to 2008, this type of capital expenditures grew in real terms by $47 \%$, whereas the output of the Russian machinery, equipment and transport production grew by only $24.3 \%$. During the crisis and adjustment growth period from 2009 to 2012, investments in ma- 
chinery, equipment and vehicles increased almost in proportion to the growth of fixed capital investments in general (by nearly 9\%). However, during the same period, the industry output saw a $1.4 \%$ reduction and a $12.2 \%$ reduction in the base for technological revamping of the economy for machinery. This means that the investment boom between 2006 and 2008 and the adjustment growth in investments from 2010 to 2012 had insignificant impact on the domestic industry production. Its dynamics lagged far behind the growth in investment demand for machinery, equipment and transport in the Russian economy.

On the other side, import of capital goods was actively increasing (Berezinskaya, 2015). Worth only USD 28 billion in 2006, it was three times as high in 2012 (USD 84 billion). Its change was visibly faster than that of the industry output and of the direct investments in technological modernization (Fig. 2).

Whereas at the beginning of the economic growth period, the cost of imported capital goods was approximately $40 \%$ of investments in machinery, equipment, and transport, it had reached $55 \%$ by the beginning of the investment drought period. By that time, the Russian economy's dependence on imports in the investment process increased noticeably.

Over the three years of the investment drought, fixed capital investments dropped by $9.1 \%$ against an even more negative trend in machinery, equipment and transport investments, which declined by $16 \%$. At the same time, the industry output decreased by only $9.9 \%$ from 2013 to 2015 . Thus, in recent years, the real decline in machinery, equipment and transport output is less drastic than the reduction in overall capital expenditures of this type.

In the meantime, while the ruble cost of imported capital goods has increased and their physical supplies have fallen during the investment drought period, the share of imported capital goods in machinery, equipment and transport investments has remained at $55 \%$.

During the investment drought period, characterized by stable (in nominal terms) investments in machinery, equipment and transport, no significant reallo-

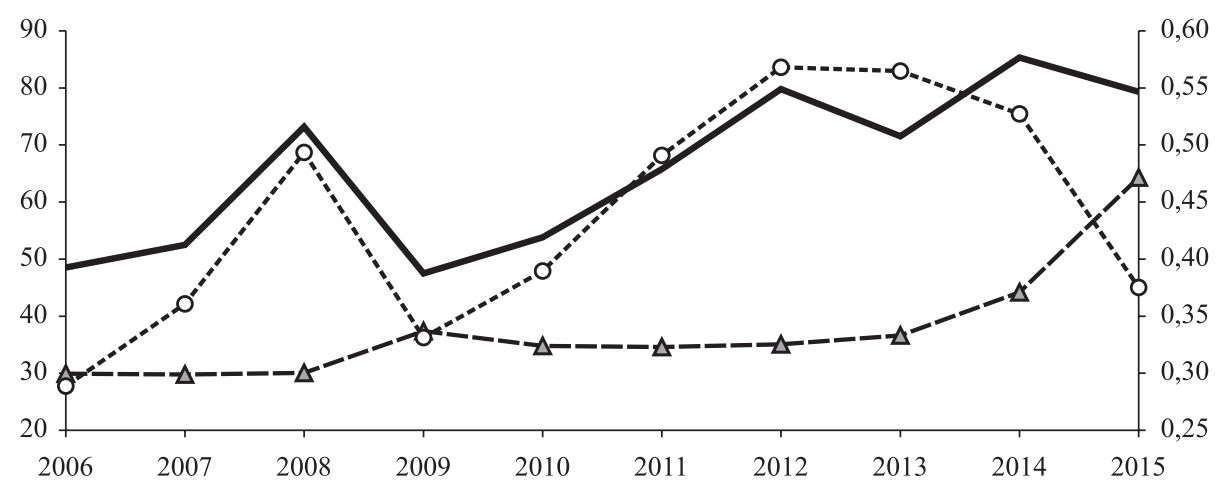

-O- Import of capital goods (USD billion, left-hand scale)

$-\Delta$ - Dual-currency basket (RUB, left-hand scale)

- Import of capital goods/investments in machinery, equipment, and transport (times, right-hand scale)

Fig. 2. Capital goods import in relation to investments in machinery, equipment, and transport, 2006-2015.

Sources: Rosstat; Bank of Russia; author's calculations. 
cation of resources has occurred between domestic and imported products that Russian companies have been purchasing or their investment projects. Despite a more moderate drop in purchases of domestic products than in imported products for investment projects, it would be premature to interpret this phenomenon as import substitution during an across-the-board drop in investments.

High dependence on fixed capital imports and depreciating national currency are holding back growth in machinery, equipment and transport investments. This is why reducing this dependence on imports and achieving a more substantial stimulus of domestic output through investment demand is an important area of investment process recovery. This entails modernizing machinery, equipment and transport industry so that it is capable of producing what can substitute for imported products. Under the existing global division of labor and the level of Russian machinery, equipment and transport sector, full import substitution for the output of high-technology companies is either not feasible or too expensive (Berezinskaya and Vedev, 2015). At the same time, there is a considerable potential for reducing dependence on fixed capital import - it requires organizing the production of relatively less complex equipment, the imported equivalents of which are currently preferable by Russian companies in terms of their technical specifications, reliability, and price. However, administrative measures for restricting procurement abroad are fraught with strategic risks: by stimulating current demand, they may significantly lower the quality of the investment process and hinder prospects for the long-term growth of Russia's economy.

\section{Structure of fixed capital investment sources}

From 1999 to 2015, corporate funds have remained the major source for financing fixed capital investments; starting from 2010, they have been an increasingly important resource for the investment process (Fig. 3).

During the adjusted growth period and the period of growth due to high demand (1999-2008), the investment process in the Russian economy was ultimately driven by increased non-public financing. Self-financing of investment projects grew more slowly; public funds supporting investment process diminished. During crisis, in 2009, while fixed capital investments decreased in nominal terms, the established composition of financing sources did not change significantly. As a result, the year 2009 was characterized by a lowest share of internal funds and a maximum share of non-public funds in fixed capital investments financing structure.

On the contrary, from 2010 to 2015, the burden of the post-crisis recovery in terms of the investment process was put on the corporate sector. Fixed capital investment expansion was ensured mainly by growth in equity participation in financing of investment projects whereas bank lending for investment projects was unstable and other non-public funds and government support for fixed capital investments declined.

The timeline for tightening resource restrictions in the investment process appears as follows.

During the investment boom (2006-2008), almost two-thirds (RUB 2.5 trillion) of the nominal expansion of investments was a result of an increase in external financing, across all channels. While income in the Russian economy grew and cheap financing flowed in, the share of equity participation in direct investment 


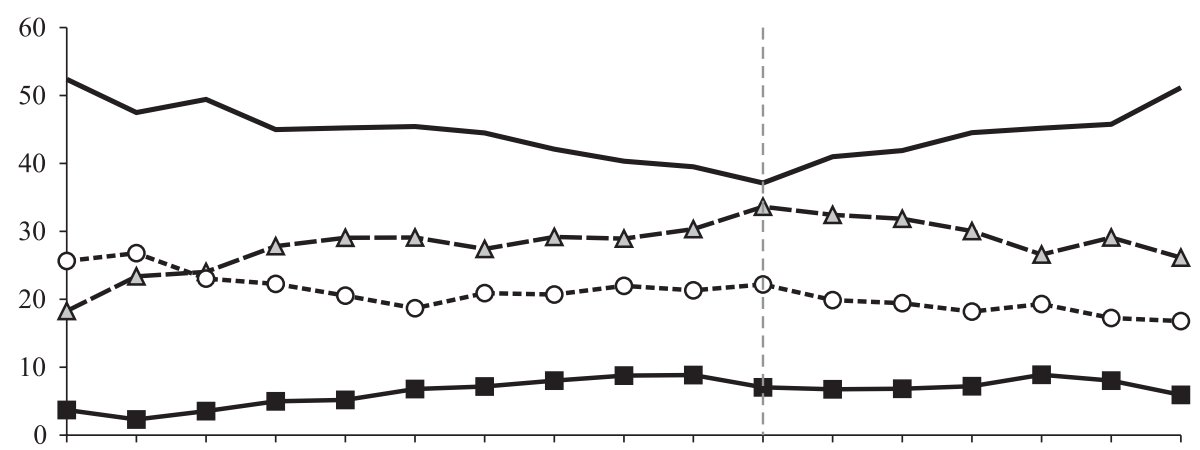

19992000200120022003200420052006200720082009201020112012201320142015

\begin{tabular}{|ll|}
\hline- Internal funds & $-\Delta$ - Other non-public borrowings ${ }^{\text {a) }}$ \\
- Loans from Russian banks & $-0-$ Public funds $^{\text {b) }}$
\end{tabular}

Fig. 3. Structure of fixed capital investments in the Russian economy by source type, 1999-2015 (\%).

\footnotetext{
a) All borrowings, except for loans from Russian banks and public funds.

b) Budgetary and non-budgetary funds.

Sources: Rosstat; author's calculations.
}

expansion was only a third (RUB 1.36 trillion over three years); however, it was enough for active investment.

During the crisis and the adjustment growth period (2009-2012), with the emergence of resource restrictions, the expansion of fixed capital investments required more active involvement by companies to finance their own investment projects. Participating equity for the expanded fixed capital investments (RUB 1.6 trillion in four years) exceeded the external funds (RUB 1.3 trillion). During this period, borrowings on the group level in the domestic and global financial markets were the main external financing source, while the role of direct government support and bank-lending diminished.

During the investment drought period (2013-2015), global financial markets funds became inaccessible, and, expectedly, Russian banks reduced their support for direct investment projects, while government funding had to be cut back. By using other sources, declining investment was partially compensated for, but internal company funds became preferred for investments expansion.

It should be stressed that growth in fixed capital investments in the Russian economy was always implemented by significant increase in external financing. On the contrary, during the investment drought period, one can see an exceptionally high dependency on equity and a reduction in opportunities for external funding of investments.

By the end of 2015, structural characteristics of the investment drought are as follows:

- over $51 \%$ of fixed capital investments were financed with equity (compared with $37 \%$ in 2009); growth in self-financing of investment projects continued to outstrip overall growth;

- following the deceleration in growth, government support for investment projects declined in nominal terms; less than $17 \%$ of investments are supported by state budget and non-budget funds (compared with 22\% in 2009); 
- lending by Russian banks is low and unstable; when economic conditions deteriorate, banks follow principles of prudence and reduce their respective lending limits: loans from Russian banks accounted for less than $6 \%$ of investment funding (compared with $7.2 \%$ in 2009);

- investments financed with funds from holding companies plummeted $(10.5 \%$ of investment sources in 2015 compared with 17.8\% from 2010 to 2012) due to the reduced access to global financial markets for Russian companies caused by economic sanctions;

- investments using other resources not mentioned above increased at the beginning of the investment drought period and barely changed in 2015; they accounted for $15.8 \%$ of all direct investments in Russia in 2014 and 2015; i.e., enterprises had extremely limited opportunities to offset decreased funding through alternative sources.

Given the persistently strong resource restrictions, almost the only real resource for expanding fixed capital investments were internal company funds. The potential for this resource to revitalize the investment process in the Russian economy is driven by (a) growth in internal corporate resources for investment and (b) incentives for companies to invest their own funds in business development (Berezinskaya and Vedev, 2014).

Internal corporate investment resources consist of amortization and after tax operating income; the volume of these resources was RUB 11.8 trillion in 2014 and RUB 14.0 trillion in 2015 (Table 3).

Having climbed on average by RUB 1.5 trillion annually in 2009-2011, internal investment resources were increasing more slowly - by RUB 0.5 trillion per year in 2012-2013, while noticeably accelerating in 2014 and 2015, rising by RUB 1.7 trillion and RUB 2.1 trillion, respectively. This means that it is actually possible for companies to trigger investment process in the Russian economy by using their own internal funds.

However, it is also important to consider corporate perception of self-financing of investment projects. It can be measured as the ratio of investments financed with internal funds to the volume of internal investment resources generated during the preceding year (Ulyukaev and Mau, 2015). This indicator used to be approximately $47 \%$ for a number of years but decreased to $44.5 \%$ in 2015 (Fig. 4).

If the tendency towards self-financing investment projects had remained at the same level, fixed capital investments using internal corporate funds would have reached RUB 5.6 trillion in 2015 (RUB 0.3 trillion more than the actual figure).

Table 3

Raising internal investment resources by Russian companies, 2008-2015 (RUB trillion).

\begin{tabular}{llllllrrr}
\hline & 2008 & 2009 & 2010 & 2011 & 2012 & 2013 & 2014 & 2015 \\
\hline Profit & 5.4 & 5.4 & 6.9 & 8.5 & 8.8 & 8.4 & 9.4 & 11.3 \\
Income tax paid & 2.5 & 1.3 & 1.8 & 2.3 & 2.4 & 2.1 & 2.3 & 2.4 \\
After-tax profit & 2.9 & 4.1 & 5.1 & 6.3 & 6.4 & 6.4 & 7.3 & 8.8 \\
Depreciation and amortization & 1.8 & 2.2 & 2.4 & 2.8 & 3.3 & 3.7 & 4.7 & $5.2^{\text {a) }}$ \\
Internal investment resources & 4.7 & 6.4 & 7.5 & 9.1 & 9.7 & 10.1 & 11.8 & $14.0^{\text {a) }}$ \\
\hline
\end{tabular}

a) Author's estimate.

Sources: Rosstat; Federal Tax Service of Russia; author's calculations. 


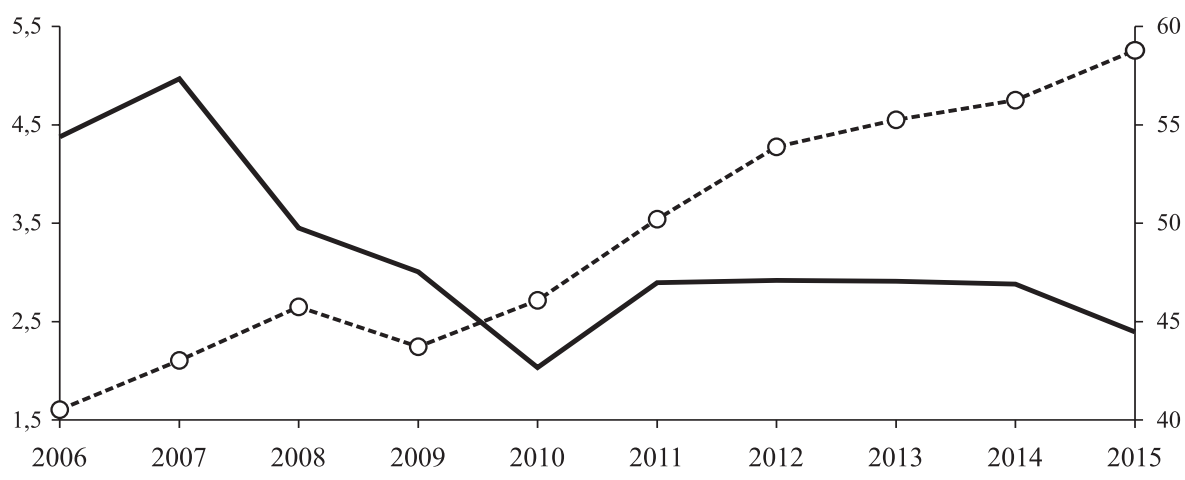

-O-- Fixed capital investments using internal corporate funds (RUB trillion, left-hand scale)

The tendency towards self-financing fixed capital investments (\%, right-hand scale)

Fig. 4. Fixed capital investments using internal corporate funds and the tendency towards self-financing investments, 2006-2015.

Sources: Rosstat; Federal Tax Service of Russia; author's calculations.

This decline may be short-lived, as it was in 2009. If the corporate tendency towards self-financing investment projects recovers, this could lead to RUB 6.6 trillion in investments in fixed capital by using internal corporate funds in 2016. However, it may also mark the beginning of a longer period of decline in companies' willingness to self-finance fixed capital investments, which could be attributable to a deteriorated business climate. If the tendency of companies to self-finance investment projects remains at the current low level of $44.5 \%$ in 2016 , based on the estimated volume of internal investment resources generated in 2015 , it can be expected that fixed capital investments using internal corporate funds would be RUB 6.2 trillion.

Thus, based on 2015 financial results, in 2016, Russian companies may increase the amount of self-financing for investment projects by approximately RUB 1.0 trillion to RUB 1.3 trillion, which would translate to $6.5 \%$ to $9.0 \%$ of overall growth in fixed capital investments in nominal terms. As shown above, an essential condition for overcoming the decrease in investment is expansion of external funding; however, internal corporate resources may be used to mitigate the decline in investments.

The extent to which the calculated expansion of fixed capital investments in nominal terms may ensure investment growth for 2016 in real terms, also depends on price trends in the Russian economy.

\section{The real and inflationary components of fixed capital investment expansion}

The nominal increase in fixed capital investments not only contributes to growth in investment projects but also compensates the rise in prices for products and services required for investment projects. This is caused by a strong inflationary trend in Russian economy and a considerable dependence on fixed capital import.

The destructive effect of inflation on investment activity in the Russian economy is highlighted in the results from 2009 through 2015. Despite stringent resource 
Table 4

Growth in fixed capital investments in current and constant prices, 2006-2015.

\begin{tabular}{|c|c|c|c|c|}
\hline & 2006-2008 & 2009-2012 & 2013-2015 & 2009-2015 \\
\hline & $\begin{array}{l}\text { investment } \\
\text { boom }\end{array}$ & $\begin{array}{l}\text { recession and } \\
\text { adjustment }\end{array}$ & $\begin{array}{l}\text { investment } \\
\text { drought }\end{array}$ & total \\
\hline $\begin{array}{l}\text { Growth in fixed capital } \\
\text { investments in current prices, } \\
\text { for the period (times) }\end{array}$ & 2.43 & 1.43 & 1.16 & 1.66 \\
\hline $\begin{array}{l}\text { Growth in fixed capital } \\
\text { investments in constant prices, } \\
\text { for the period (times) }\end{array}$ & 1.600 & 1.088 & 0.909 & 0.990 \\
\hline Investment deflator (times) & 1.52 & 1.32 & 1.27 & 1.67 \\
\hline \multicolumn{5}{|l|}{ For reference: } \\
\hline Industrial producer price index & 1.53 & 1.32 & 1.21 & 1.60 \\
\hline $\begin{array}{l}\text { Growth in dual-currency basket } \\
\text { value (times) }\end{array}$ & 0.96 & 1.17 & 1.84 & 2.14 \\
\hline
\end{tabular}

Note: In the industrial sector, except for the fossil fuel production and consumer product manufacturing facilities. Sources: Rosstat; Bank of Russia; author's calculations.

restrictions during this period, economic agents managed to increase fixed capital investments by two-thirds in nominal terms. At the same time, this increase was not meaningful after price adjustment: fixed capital investments did not change in real terms; the increase in investments was completely attributable to increased prices for products and services required for investment projects (Table 4).

The investment deflator trend is largely driven by growth in industrial producer prices. From 2006 to 2008, and from 2009 to 2012, the investment deflator almost matched the producer price index, which excludes fossil mineral extraction and manufactured consumer goods (the latter industry's supply is insignificant for investment projects). However, during the investment drought period, given the dependence on fixed capital imports and significant depreciation of the national currency, the investment deflator exceeded the producer price index.

From 2013 to 2015, the investment process in the Russian economy was under considerable pressure from inflation factors. As producer prices rose by $21 \%$ and the ruble fell by $84 \%$ (in terms of the dual-currency basket), cost of products and services required for investment projects grew by $27 \%$. The significant appreciation of investment projects led to a situation, in which a $16 \%$ growth in fixed capital investments in nominal terms was equivalent to a $9.1 \%$ reduction in real terms.

In the past, inflation had always been a limiting factor for fixed capital investments in Russia. However, during the post-crisis period, its effect abated slightly: the annual increase in investment project prices was between $4.9 \%$ and $8.8 \%$ from 2009 to 2014, with a distinctly positive trend from 2012 to 2014. In 2015, rising prices for investment projects accelerated.

Under stringent resource restrictions on the investment process, in order to resume real growth in fixed capital investments and overcome the investment drought, a reversion to decelerating inflation for investment project costs is needed. This can be achieved with a set of measures aimed at slowing down price growth (including the tariff policy), decreasing the dependence on fixed capital import and improving management of projects, especially of those financed with public funds. 


\section{Conclusions: Opportunities and approaches for overcoming the investment drought}

Based on the analysis of the structural characteristics, it is advisable to focus economic policy on the following objectives in order to overcome the investment drought outlined above:

Expanding the volume of internal investment resources of Russian companies and reinforcing the tendency of companies to self-finance investment projects. This assumes the whole set of measures aimed to enhance Russian business climate: increasing transparency of control and supervision; protecting rights of owners and investors (Mau, 2016); improving competition in the domestic market; supporting export of Russian products and services; assisting import substitution, etc.

Targeted lending for investment projects in key economic activities (mainly in machinery, equipment and transport production for acceleration of import substitution and decrease of the dependence on fixed capital import). This is gaining importance in the current aggravating economic environment, in which banks, guided by the principle of prudence, are reducing their long-term lending limits and cutting participation in investment projects (Berezinskaya, 2016b).

State support of infrastructure projects. This would encourage activation of non-residential property investments, with a further resumption of growth in fixed capital investments in the construction sector that make a major contribution to the overall invested capital.

Subsidized mortgage lending plans and other measures to support housing construction. This would allow to maintain fixed capital investment drivers that were active during the investment drought.

Overcoming limited access to global financial market resources as soon as possible. This is an essential resource condition for overcoming the decline in investments, since internal corporate funds can only mitigate but not resolve this issue.

Import substitution in machinery and construction. This would decrease the dependence on import and the limiting effect of the national currency exchange rate on fixed capital investments as well as increase the effect of investment demand on domestic demand in the economy. The focus may be not on complicated high-tech projects (too expensive, if feasible at all) but rather on organizing the production of moderately complex equipment and parts, which, due to their specifications and prices, currently cannot compete with analogous imported ones.

Mitigating inflation pressure in the economy. This would allow to achieve higher efficiency of fixed capital investments in terms of increasing capital expenditures in real terms. This covers all economic policy measures, including tariff policy, measures to increase domestic markets competition, support of import substitution (limiting the effect of the ruble exchange rate on investment cost).

Improving management of investment projects, primarily those financed with public funds. Supervising proper spending and preventing unreasonable increases in project costs may substantially diminish the inflation component in expanded fixed capital investments.

These measures addressing direct investment reactivation were suggested on the basis of the analysis of fixed capital investment in the past years and during 
the current investment drought period. Undoubtedly, the above list is not exhaustive and can be extended with certain investment incentives. Importantly however, under persistent stringent resource restrictions, it is necessary to make use of all available economic policy tools to revitalize the investment process.

\section{References}

Aganbegyan, A. (2015). How national budget can provide economic growth. Voprosy Ekonomiki, 7 , 142-151 (In Russian).

Berezinskaya, O. (2015). National currency rate and the russian economy dependence on import. Ekonomicheskaya Politika, 1, 112-125 (In Russian).

Berezinskaya, O. (2016a). Dynamics of capital investment. Ekonomicheskoe Razvitie Rossii, 4, 18-21 (In Russian).

Berezinskaya, O. (2016b). Lending to the non-financial sector: Opportunities and limitations. Voprosy Ekonomiki, 3, 63-74 (In Russian).

Berezinskaya, O., \& Vedev, A. (2014). Investments in the Russian economy: Their potential and activation directions. Voprosy Ekonomiki, 4, 4-16 (In Russian).

Berezinskaya, O., \& Vedev, A. (2015). Dependency of the Russian industry on imports and the strategy of import substitution industrialization. Voprosy Ekonomiki, 1, 103-115 (In Russian).

Mau, V. (2016). Anti-crisis measures or structural reforms: Russian economic policy in 2015. Russian Journal of Economics, 2 (1), 1-22.

Ulyukaev, A., \& Mau, V. (2015). From economic crisis to economic growth, or how to prevent the crisis from turning into stagnation. Voprosy Ekonomiki, 4, 5-19 (In Russian).

Vedev, A., \& Kosarev, A. (2012). Quantitative assessments of institutional improvements' impact on economic growth in Russia. Ekonomicheskaya Politika, 1, 50-65 (In Russian). 